\title{
STUDI DINAMIKA KUALITAS AIR DAS CILIWUNG
}

\author{
Hasmana Soewandita dan Nana Sudiana \\ Pusat Teknologi Sumberdaya Lahan Wilayah dan Mitigasi Bencana - BPPT \\ JI. MH. Thamrin No. 8 Jakarta Pusat
}

\begin{abstract}
Ciliwung River which has upstream in Bogor, while downstream in Jakarta presence has very important role for the region in its path. Positive role of the river for the public interest in this area include the need of clean water sources, irrigation / agriculture, industry and others. Conversely Ciliwung River is also a source of flood disaster in Jakarta. Will consider its use, the risk of disaster resources and environmental burdens are received by the waters and the water catchment area is very large, then the existence of river quality should be monitored both the water catchment conditions or water quality. For future purposes, it would require a management with specific deadlines (5 th, 10 th, 15 th) and targets based on the quality of the water quality standards (BMA) class III, II and I. The results of the current monitoring parameters BOD, COD, fecal Coli, Coliform has a value above the threshold of water quality standards specified. While DO in the downstream segment has a value below the water quality standards. Other parameters such as $\mathrm{pH}$, TSS and nitrogen have a greater trend downstream, but the value of the water quality is still under water quality standards that are targeted.
\end{abstract}

Keywords: Water quality, Water Quality standards, Ciliwung river.

\section{PENDAHULUAN}

\subsection{Latar Belakang}

DAS Ciliwung dikenal sangat fenomenal. Indikasi bencana banjir di Jakarta yang terjadi beberapa kali dalam beberapa tahun terakhir ini merupakan salah satu "ulah" aliran Sungai Ciliwung. Kerusakan aliran (bagian bantaran) dan daerah aliran sungai Ciliwung sebenarnya akibat dampak dari kegiatan manusia yang hidup di DAS tersebut. Kebijakan yang dianggap tidak pro lingkungan disinyalir juga menjadi penyebab degradasi lingkungan DAS Ciliwung. Kebijakan tata ruang terutama bagian hulu DAS Ciliwung yang tidak dilaksanakan secara konsisten semakin menurunkan kualitas lingkungan DAS Ciliwung. Perubahan lahan dari kawasan konservasi untuk kawasan pemukiman di kawasan Puncak, meningkatkan aliran permukaan sampai ke badan sungai, sehingga secara otomatis kemampuan badan sungai menampung aliran permukaan juga akan semakin kecil, dan akhirnya berdampak pada banjir dikawasan hilir. Selain beban aliran permukaan yang semakin besar, aliran Sungai Ciliwung juga terbebani oleh limbah industri dibagian segmen tengah DAS serta limbah domestik dari masyarakat yang tinggal sepanjang aliran Sungai Ciliwung.

Secara administrasi Daerah Aliran Sungai Ciliwung melewati Kabupaten Bogor, Kota Bogor, Kota Depok dan DKI Jakarta. Karena Jakarta sebagai ibu kota Negara, maka kota ini masih menjadi magnet bagi orang untuk mencari nafkah. Konsekwensi logis yang harus dipikul olek kota penyangga adalah penyediaan ruang untuk pemukiman. Akibat fenomena ini Depok dan Bogor akan mendapat beban untuk perubahan tata ruang terutama proyeksi kawasan budidaya (lahan sawah, tegalan bahkan kawasan konservasi) untuk dirubah menjadi kawasan pemukiman. Peningkatan industrialisasi terutama di segmen DAS bagian tengah juga tidak bisa dihindari. Sehingga langsung ataupun tak langsung bebab ekologis DAS Ciliwung juga akan semakin merosot. Beban ekologis pada tata ruang juga akan menyebabkan beban ekologis pada aliran Sungai Ciliwung baik kuantitas maupun kualitas aliran Sungai Ciliwung.

Menyadari bahwa Ciliwung sangat strategis keberadaannya, maka pengelolaan Ciliwung harus terpadu dan melibatkan multi sector. Salah satu pengelolaan kedepan yang sangat strategis adalah air Sungai Ciliwung sebagai salah satu sumber air minum, sehingga pengelolaan dan pemantauan kualitas air harus ditangani secara cermat. Untuk melihat fenomena kondisi kualitas air Sungai Ciliwung dari hulu dan hilir maka perlu dilakukan penelitian kondisi kualitas air tersebut, sehingga keberadaan, dan kualitasnya dapat diketahui dalam rangka rekomendasi arahan pengelolaan DAS Ciliwung masa depan. 


\subsection{Tujuan}

Tujuan dari studi adalah untuk mengetahui kondisi dinamika kualitas air Sungai Ciliwung dari hulu hingga hilir, yang diperkirakan beban ekologisnya semakin berat berkaitan perubahan kondisi penggunaan lahan, industrialisasi dan akitivitas manusia.

\section{METODOLOGI}

\subsection{Alat dan Bahan}

Peralatan yang digunakan untuk studi ini adalah seperangkat alat pengukuran kualitas air yaitu $\mathrm{pH}$ meter, dan water sampler, ember. Sedangkan bahan yang digunakan bahan-bahan kimia untuk analisis laboratorium kualitas air.

\subsection{Tempat dan Waktu}

Lokasi atau wilayah untuk melakukan studi ini adalah sepanjang aliran Sungai Ciliwung dari mulai hulu hingga hilir yang merepresentasikan segmen hulu, tengah dan hilir. Untuk mewakili segmen-segmen tersebut maka lokasi yang dipilih (16 lokasi) untuk pengukuran dan pengambilan sample air adalah sebagai berikut: Masjid Atta'awun, Cisampai, Leuwi Malang, Jembatan Gadog, Pasir Angin, Katulampa, Kebun Raya, Pasir Jambu, Pondok Rajek, Jembatan Panus, Jembatan Kelapa Dua, Condet, Manggarai, Kwitang, Gn. Sahari, Pantai Indah Kapuk. Sedangkan waktu pelaksanaan studi dilakukan pada bulan September 2007.

\subsection{Metoda}

Metoda pengukuran kondisi kualitas air Sungai Ciliwung didasarkan kondisi keterwakilan segmen hulu, tengah dan hilir. Segmen-segmen ini merepresentasikan kondisi dan karakteristik penggunaan lahan. Dimana jenis dan kekomplekan penggunaan lahan akan sangat mempengaruhi beban ekologi DAS Ciliwung. Metoda pengukuran dan sampling air yaitu pengambilan sampel air dengan water sampler pada tiap titik dengan keterwakilan pinggir, tengah, pinggir serta bagian atas, tengah dan bawah dari badan air tersebut. Sampel air dianalisis di Laboratorium BPLH DKI Jakarta yang mewakili parameter : $\mathrm{pH}, \mathrm{DO}, \mathrm{BOD}, \mathrm{COD}$, TSS, Fecal Coli, Coliform, Fosfat dan N Total.

\section{DISKRIPSI UMUM DAS CILIWUNG}

\subsection{Kondisi Iklim}

DAS Ciliwung Bagian Hulu mempunyai curah hujan rata-rata antara $2.929-4.956 \mathrm{~mm} /$ tahun. Perbedaan bulan basah dan kering sangat menyolok yaitu 10,9 Bulan basah per tahun dan hanya 0,6 Bulan kering per tahun. Tipe iklim DAS Ciliwung Bagian Hulu menurut sistem klasifikasi Smith dan Ferguson (1951) yang didasarkan pada besarnya curah hujan, yaitu Bulan Basah (> $200 \mathrm{~mm}$ ) dan Bulan Kering $(<100 \mathrm{~mm})$ adalah termasuk kedalam Type A.

Sedangkan wilayah DAS Ciliwung bagian tengah yang secara wilayah administrasi berada di Kabupaten Bogor bagian Utara dan Kota Depok yang berbatasan dengan DKI Jakarta. Wilayah Bogor bagian Utara ini memiliki curah hujan rata-rata 197,3 mm/bulan, dengan curah hujan maksimum 449,0 pada bulan Nopember dan curah hujan minimum 32,0 pada bulan Juli. Selain hal tersebut juga dapat dijelaskan bahwa Kota Bogor merupakan dataran tinggi dengan suhu udara rata-rata setiap bulannya adalah $26^{\circ} \mathrm{C}$ dengan kelembaban udara $\pm 70 \%$ dan suhu udara terndah adalah $21^{\circ} \mathrm{C}$ serta suhu udara tertinggi $30^{\circ} \mathrm{C}$.

Banyaknya curah hujan setiap tahunnya rata-rata berkisar $3.500 \mathrm{~mm}$ sampai $4.000 \mathrm{~mm}$ dan curah hujan terbesar adalah pada bulan April. Sedangkan berdasarkan data pemeriksaan hujan di Stasiun Depok, Pancoran Mas, banyaknya curah hujan antara $1-591 \mathrm{~mm}$, dan banyaknya hari hujan antara $10 \mathrm{~s} / \mathrm{d} 23$ hari, yang terjadi pada bulan Oktober dan Desember. Curah hujan rata-rata sekitar $327 \mathrm{~mm}$.

\subsection{Tanah dan Geologi}

Jenis-jenis tanah yang ada di wilayah Sub DAS Ciliwung Bagian Hulu meliputi jenis komplek Aluvial Kelabu, Andosol Coklat dan Regosol Coklat, Andosol Coklat, Latosol Coklat, Latosol Coklat Kemerahan dan Latosol Coklat. Hal ini didasarkan atas Peta Tanah Tinjau untuk Kabupaten Bogor dan Kota Bogor skala 1 : 250.000 dari Pusat Penelitian Tanah Bogor. Dari jenis-jenis tanah diatas, jenis tanah yang tersebar luas di DAS Ciliwung Bagian Hulu adalah Latosol Coklat Kemerahan dan Latosol Coklat sebesar $32,89 \%$ dari total luas areal DAS Ciliwung Bagian Hulu.

Sedangkan formasi geologi DAS Ciliwung bagian hulu dibangun oleh formasi geologi vulkanik yaitu komplek utama Gunung Salak dan komplek Gunung Pangrango.

\subsection{Topografi dan Bentuk Wilayah}

Berdasarkan bentuk topografinya, wilayah DAS Ciliwung hulu bervariasi antara bentuk datar, landai, agak curam, curam sampai dengan sangat curam. Pembagian wilayah DAS Ciliwung Bagian Hulu berdasarkan topografi dan 
bentuk wilayah diklasifikasikan kedalam bentuk kelas lereng $0-15 \%, 15-40 \%,>40 \%$.

DAS Ciliwung hulu mempunyai wilayah dengan kelerengan antara $0-15 \%$ menempati areal kurang lebih 34,11 \% luas wilayahnya, sedangkan diatas antara $15 \%$ - $40 \%$ menempati areal $25,77 \%$ luas wilayahnya dan kelerengan > $40 \%$ menempati areal 40,12\% dari luas wilayahnya. Dengan melihat sebarannya berdasarkan dominansi jenis kelerengannya tersebut, maka wilayah DAS Ciliwung hulu mempunyai potensi erosi yang sangat besar sehingga dalam perlakuannya perlu memperhatikan kaidah-kaidah konservasi tanah, baik vegetatif maupun teknik sipil.

\subsection{Tataguna Lahan}

Penggunaan lahan berupa hutan di DAS Ciliwung Bagian Hulu masih sekitar 5.075,49 Ha atau sekitar 34,13\% dari keseluruhan luas wilayah DAS bagian hulu. Penggunaan lahan dibagian hulu terdiri untuk lahan perkebunan, pertanian lahan kering, sawah dan pemukiman. Di segmen tengah DAS Ciliwung penggunaan lahan dari mulai pertanian/sawah, tegalan, pemukiman dan industri. Sedangkan disegmen bagian hilir yang secara administrasi sudah masuk DKI Jakarta sebagian besar merupakan kawasan pemukiman yang sangat padat. Beban ekologi kawasan hilir DAS Ciliwung semakin berat terutama aspek kualitas airnya dikarenakan dampak industrialisasi kawasan tengah dan pemukiman padat terutama di Depok dan DKI Jakarta.

\subsection{Kondisi Sosial ekonomi}

Berdasarkan data dari Biro Pusat Statistik (BPS), jumlah penduduk Kota Depok pada Tahun 2005 sebesar 1.374.903 jiwa. Jumlah ini meningkat cukup pesat bila dibandingkan dengan jumlah penduduk tahun sebelumnya. Laju pertumbuhan penduduk Kota Depok sebesar $6.75 \%$. Sedangkan kabupaten Bogor berdasarkan statistik tahun 2005, jumlah penduduknya sekitar 3.700.207 jiwa dengan tingkat kepadatan penduduk 1.549 jiwa $/ \mathrm{m}^{2}$. Untuk wilayah DKI Jakarta jumlah penduduk pada tahun 2009 sekitar 8.513.385 jiwa dengan tingkat kepadatan penduduk $7.3047 \mathrm{jiwa} / \mathrm{m}^{2}$.

\section{KONDISI KUALITAS AIR DAS CILIWUNG}

Pemantauan kualitas air secara spasial dimaksudkan untuk menganalisis perubahan atau dinamika kualitas air berdasarkan sebaran spasial mulai dari hulu Sungai Ciliwung yaitu lokasi pemantauan Masjid At-Ta'awun hingga hilir yaitu lokasi pemantauan Pantai Indah Kapuk.
Pemantauan dilakukan pada 16 titik pemantauan yang tersebar pada segmen hulu sebanyak 6 titik yaitu : Masjid At-Ta'awun, Cisampai, Leuwi Malang, Jembatan Gadog, Pasir Angin, dan Katulampa. Pada segmen tengah meliputi 3 titik sampling yaitu Kebun Raya, Pasir Jambu, dan Pondok Rajek, sedangkan pada segmen hilir meliputi 7 titik sampling yaitu Jembatan Panus, Jembatan Kelapa Dua, Condet, Manggarai, Kwitang, Gunung Sahari, dan Pantai Indah Kapuk (PIK). Parameter yang dipantau merujuk kepada Master Plan pemulihan kualitas air Sungai Ciliwung yang terdiri dari parameterparameter : fisik ( $\mathrm{pH}, \mathrm{TSS})$, parameter kimia (BOD, COD, DO, Phosphat, dan Nitrogen Total), serta parameter biologi (Fecal Coli dan Coliform).

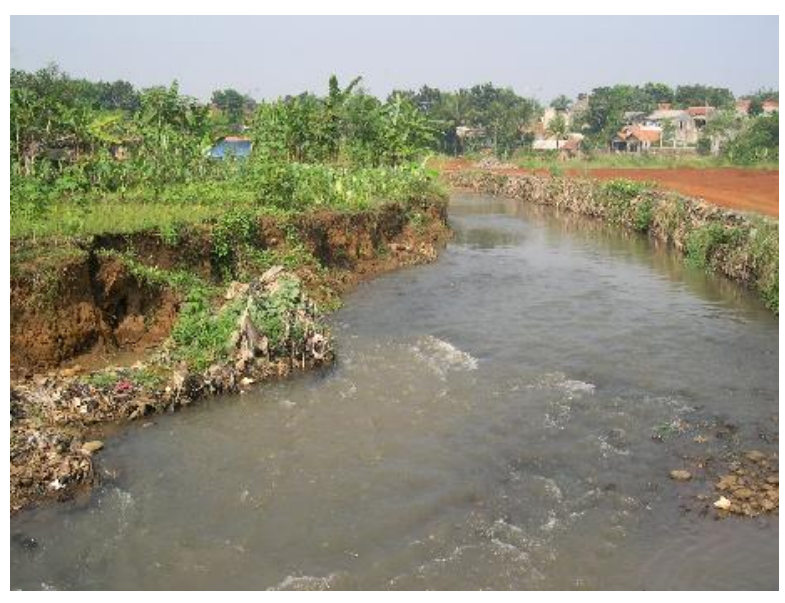

Gambar 1. Kondisi bantaran sungai Ciliwung Hulu di kawasan Puncak, nampak telah berubah fungsi alaminya menjadi kawasan pemukiman.

Pemantauan dilakukan untuk melihat keterkaitan antara dinamika ekosistem perairan Sungai Ciliwung dengan ekosistem Daerah Aliran Sungai (DAS) yang merupakan tempat berbagai aktivitas penduduk seperti permukiman, perkotaan, industri, pertanian, perkebunan, pariwisata, dan lain-lain. Sungai Ciliwung saat ini menjadi perhatian penting karena merupakan salah satu sungai yang memberikan kontribusi besar bagi masyarakat yang tinggal di wialyah DAS-nya. Kontribusi tersebut baik bersifat positif seperti sumber air minum, MCK, irigasi pertanian, perkebunan, perikanan, industri, maupun bersifat negativ yaitu banjir. Oleh karena itu hasil pemantauan ini sangat diperlukan bagi masukan dalam membuat rencana dan tindakan pemulihan kualitas air Sungai Ciliwung secara keseluruhan.

Analisis hasil pemantauan didasarkan pada peruntukan air sungai dan standar Baku Mutu Air (BMA) Peraturan Pemerintah (PP) Nomor 82 Tahun 2001 tentang Pengelolaan Kualitas Air dan Pengendalian Pencemaran Air (Tabel 1). 


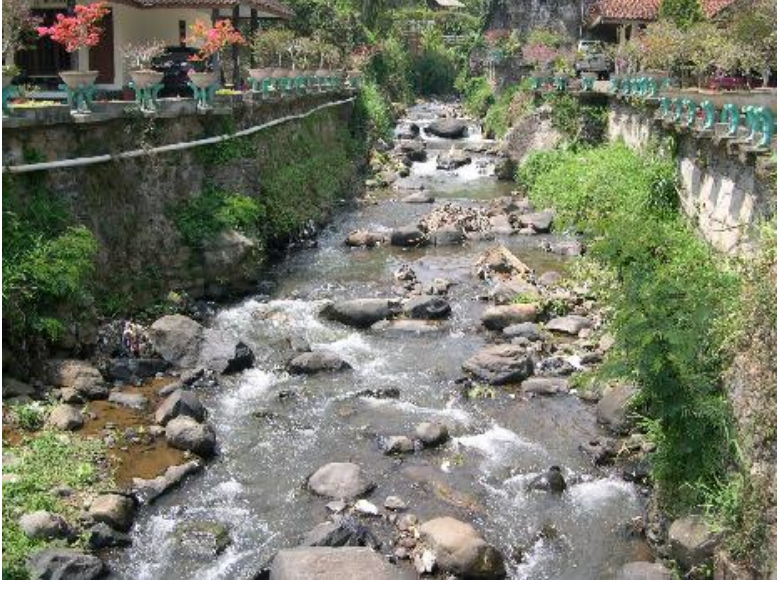

Gambar 2. Tekanan ekologi aliran Sungai Ciliwung segmen tengah akibat perubahan lahan untuk kawasan pemukiman.

Tabel 1. Baku Mutu Air (BMA) Sesuai dengan Kelas Peruntukan Sungai

\begin{tabular}{|r|l|c|c|c|c|}
\hline No & Parameter & I & II & III & IV \\
\hline 1 & pH & $6-9$ & $6-9$ & $6-9$ & $5-9$ \\
\hline 2 & BOD & 2 & 3 & 6 & 12 \\
\hline 3 & COD & 10 & 25 & 50 & 100 \\
\hline 4 & DO & 6 & 4 & 3 & 0 \\
\hline 5 & TSS & 50 & 50 & 400 & 400 \\
\hline 6 & Fecal Coli & 100 & 1000 & 2000 & 2000 \\
\hline 7 & Total Coliform & 1000 & 5000 & 10000 & 10000 \\
\hline 8 & Fosfat & 0,2 & 0,2 & 1 & 5 \\
\hline 9 & N-Total & 10 & 10 & 20 & 20 \\
\hline
\end{tabular}

Hasil pemantauan kualitas air Sungai Ciliwung pada periode September 2007, disajikan pada Tabel Lampiran 1. Dari Tabel tersebut untuk parameter $\mathrm{pH}$ nilainya berada pada skala BMA pada berbagai peruntukan air sungai yaitu berkisar antara 6,6 - 7,6. Parameter $B O D$, diseluruh titik pengamatan memiliki nilai yang melebihi BMA yaitu pada kisaran antara $5,65 \mathrm{mg} / \mathrm{L}$ sampai dengan $60 \mathrm{mg} / \mathrm{L}$. Parameter COD secara umum memiliki nilai aman pada BMA untuk kelas air sungai III dan IV, hanya beberapa titik di hulu sungai yang masuk pada BMA kelas air II. Parameter DO untuk segmen hulu dan tengah memiliki nilai yang aman pada berbagai kelas peruntukan air, namun untuk segmen hilir memiliki nilai yang rendah dan hanya cocok untuk peruntukkan kelas IV. Parameter biologi fecal coli dan total coliform memiliki nilai yang sangat tinggi jauh dari BMA pada berbagai kelas bahkan kelas terendah sekalipun, hal ini menunjukkan kondisi sungai Ciliwung yang sudah tercemar berat oleh limbah kotoran manusia. Untuk parameter $\mathrm{P}$ dan $\mathrm{N}$ memiliki nilai yang masih berada di bawah ambang batas BMA. Analisis rinci setiap parameter tersebut akan diuraikan pada sub bab berikut ini.

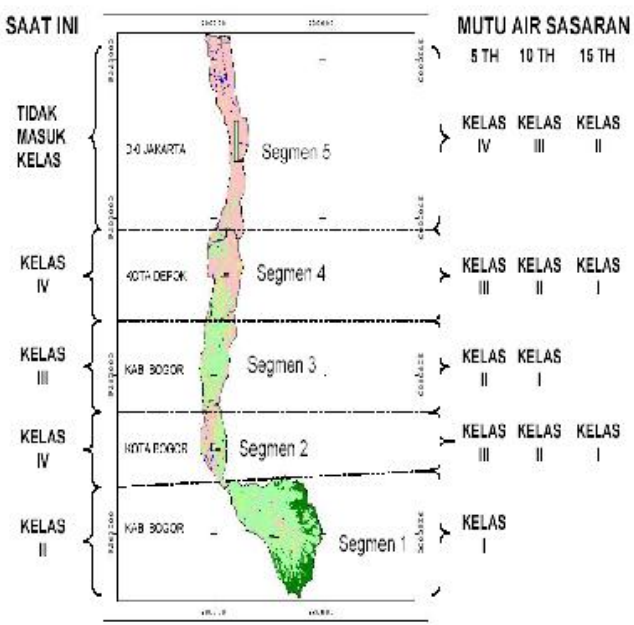

Gambar 3. Jalur pemantauan kualitas air dari hulu hingga hilir Sungai Ciliwung dengan target kelas baku mutu air tiap segmen.

\section{a. Derajat Keasaman (pH)}

Parameter $\mathrm{pH}$ menunjukkan intensitas keasaman atau alkalinitas dari suatu cairan encer, dan mewakili konsentrasi hydrogen ionnya. $\mathrm{pH}$ tidak mengukur seluruh keasaman atau seluruh alkalinitas. Karena selalu terdapat beberapa pemisahan molekul-molekul dalam larutan cairan, maka selalu terdapat hydrogen bebas dan ion hidroksil. Kelebihan salah satu molekul-molekul itulah yang menyebabkan larutan menjadi masam atau mengandung alkali. Dalam air murni yang tidak bersifat asam atau mengandung alkali, jumlah ion-ion hydrogen adalah sama dengan ion-ion hydroksil. Apabila terdapat kelebihan ion hydrogen, maka air menjadi masam, dan kekurangan ion-ion hidrogen menyebabkan air itu mengandung alkali. Jadi konsentrasi ion hydrogen bertugas sebagai penunjuk mengenai reaksi air, air limbah, atau air selokan.

Pengukuran $\mathrm{pH}$ adalah suatu yang penting karena banyak reaksi kimia dan biokimia penting terjadi pada tingkat $\mathrm{pH}$ yang khusus atau dalam lingkungan $\mathrm{pH}$ yang sangat sempit. Oleh karena itu hal ini penting untuk pengendalian pencemaran atau limbah. Pengendalian pencernaan anaerobic dari zat-zat organik sangat ditentukan olah $\mathrm{pH}$, pada tingkat $\mathrm{pH} 5$ tingkat keasaman pencernaan jadi tidak normal. Hal ini karena pada pH kurang dari 5 atau lebih dari 10 , proses-proses aerobic biologis menjadi kacau. 


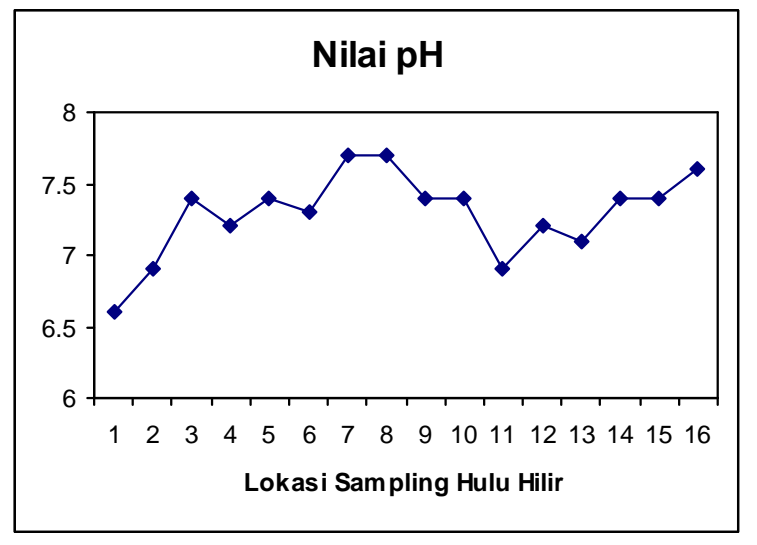

Gambar 4. Intensitas Keasaman Sungai Ciliwung Hulu-Hilir

Hasil pengukuran tingkat keasaman $(\mathrm{pH})$ pada badan air Sungai Ciliwung berkisar antara 6,6 hingga 7,6, dengan pola dari hulu hingga hilir mengalami peningkatan (Gambar 4). Hal ini karena semakin ke hilir masuknya limbah domestik semakin tinggi, khususnya yang mengandung bahan-bahan alkali seperti sabun yang menyebabkan perairan semakin bersifat basa. Namun demikian nilai tersebut masih dalam kisaran intensitas keasaman $(\mathrm{pH})$ normal. Dan berdasarkan BMA PP No. 82 Tahun 2001, nilai tersebut termasuk aman pada berbagai tingkatan peruntukan air sungai.

\section{b. Kebutuhan Oksigen Biokimiawi (Biochemical Oxygen Demand)}

Kebutuhan oksigen biokimia (BOD) merupakan salah satu parameter paling penting yang diukur untuk menentukan kekuatan atau daya cemar air limbah, sampah industri, selokan, sungai yang telah tercemar. Pemantauan BOD adalah mengukur jumlah zat organik yang kemungkinan akan dioksidasi oleh kegiatankegiatan bakteri aerobik (bakteri yang hidup dengan oksigen) biasanya dalam masa lima hari pada $20^{\circ} \mathrm{C}$. Jadi $\mathrm{BOD}$ adalah jumlah oksigen yang dibutuhkan oleh bakteri dalam menyeimbangkan zat-zat organik yang dapat dibusukkan di bawah keadaan-keadaan aerobik. Nilai-nilai BOD air limbah sangat berbeda-beda berkisar antara $100 \mathrm{mg} / \mathrm{L}$ sampai $600 \mathrm{mg} / \mathrm{L}$. Untuk air limbah domestik nilainya sekitar 200 $\mathrm{mg} / \mathrm{L}$. Apabila limbah tersebut di buang ke saluran atau sungai akan mengalami pengenceran dan batas maksimum yang ditolerir adalah sebesar $4 \mathrm{mg} / \mathrm{L}$. Berdasarkan PP No. 82 Tahun 2001 batas maksimumnya 2 mg/L untuk kelas I dan $12 \mathrm{mg} / \mathrm{L}$ untuk kelas IV.

Kadar BOD di perairan Sungai Ciliwung menunjukkan angka berkisar antara $5,65 \mathrm{mg} / \mathrm{L}$ hingga $60 \mathrm{mg} / \mathrm{L}$. Berdasarkan target kelas air yang ingin dicapai setiap segmen sungai angka tersebut melampaui BMA, dimana pada segmen hulu sungai yang masuk wilayah Kabupaten Bogor targetnya adalah kelas I, dan Kota Bogor targetnya kelas III, dengan batas BOD maksimum adalah 2 dan $3 \mathrm{mg} / \mathrm{L}$, sementara hasil analisis di beberapa lokasi pada segmen tersebut berkisar antara 5,65 sampai $14,5 \mathrm{mg} / \mathrm{L}$. Pada segmen tengah yaitu wilayah administrasi Kabupaten Bogor dan Kota Depok masingmasing memiliki target kelas II dan III, dengan batas BOD maksimum adalah 3 dan $6 \mathrm{mg} / \mathrm{L}$, sementara hasil analisis menunjukkan nilai antara 9,65 sampai $20,50 \mathrm{mg} / \mathrm{L}$. Pada segmen hilir yaitu di wilayah Jakarta memiliki target kelas IV dengan kadar BOD maksimum $12 \mathrm{mg} / \mathrm{L}$, sementara hasil pengukuran menunjukkan nilai dengan kisaran antara 21,80 - 60 mg/L. Berdasarkan uraian tersebut maka dari aspek parameter BOD kondisi Sungai Ciliwung dalam kondisi di atas BMA atau tercemar.

Secara spasial dari hulu ke hilir menunjukkan peningkatan kadar BOD (Gambar 5 ), hal ini terkait erat dengan sumber dari BOD tersebut yaitu limbah domestik dimana semakin ke hilir semakin padat permukiman sebagai sumber limbah domestik.

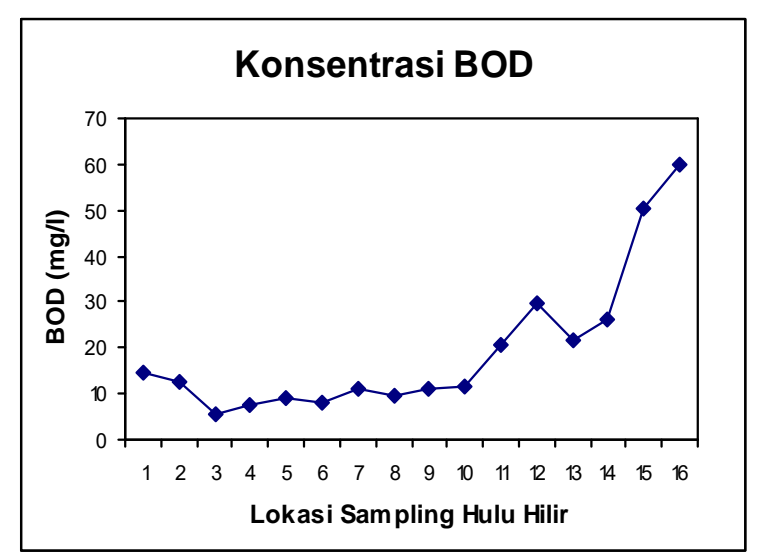

Gambar 5. Konsentrasi BOD di Sungai Ciliwung Hulu-Hilir

\section{c. Kebutuhan Oksigen Kimiawi (Chemical Oxygen Demand)}

Parameter ini digunakan secara umum untuk mengukur kekuatan pencemaran air dari limbah domestik maupun sampah industri. Adapun unsur kimia yang diukur adalah jumlah oksigen yang dibutuhkan untuk mengoksidasi zat-zat organik pada sampel. Pengamatan COD ini cukup bermanfaat untuk penyusunan rencana pengelolaan pengendalian dan pemulihan kualitas air sungai, hanya di segmen hulu terdapat dua titik sampling yang memiliki nilai COD sedikit melebihi BMA yang diinginkan yaitu sebesar 25,71 dan $28,57 \mathrm{mg} / \mathrm{L}$ dari standar 
sebesar $10-25 \mathrm{mg} / \mathrm{L}$. Sedangkan pada segmen tengah dan hilir memiliki nilai COD dibawah BMA yang diinginkan yaitu berkisar antara 6,18-8,5 $\mathrm{mg} / \mathrm{L}$ (tengah) dan 30,48-98,24 mg/L (hilir), batas maksimum COD tengah : $50 \mathrm{mg} / \mathrm{L}$ dan hulu : 100 $\mathrm{mg} / \mathrm{L}$.

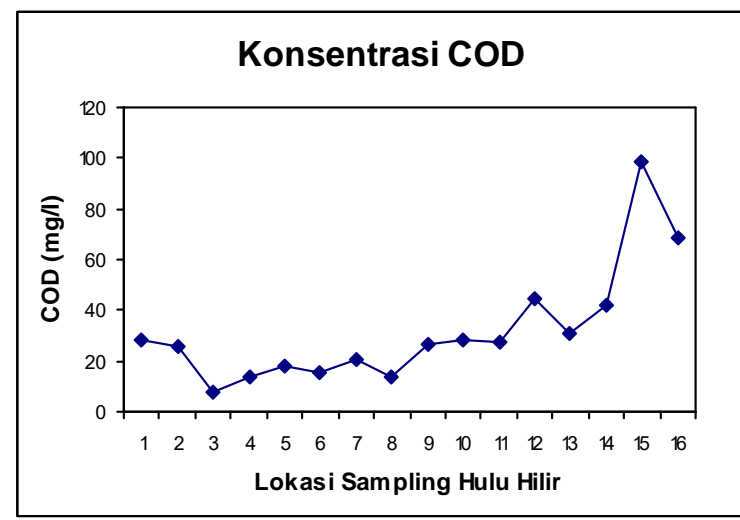

Gambar 6. Konsentrasi COD di Sungai Ciliwung Hulu-Hilir

Secara umum distribusi COD secara spasial dari hulu ke hilir menunjukkan peningkatan, hal ini terkait dengan meningkatnya sumber bahan-bahan yang teroksidasi yang berasal limbah domestik yang dihasilkan dari berbagai aktivitas manusia yang berada di dalam DAS Sungai Ciliwung. Semakin ke hilir semakin tinggi tingkat pengunaan lahan DAS untuk berbagai aktivitas seperti permukiman perkotaan perkantoran, industri, dan lain-lain.

\section{d. Oksigen Terlarut (Dissolve Oxygen)}

Parameter ini penting untuk menjamin keadaan-keadaan aerobik dalam daerah perairan yang menampung zat-zat pencemar dalam bentuk air limbah, sampah-smpah industri, termasuk limbah domestik. Dalam mengendalikan pencemaran aliran-aliran air perlu memperhatikan kondisi habitat untuk perkembangan biota perairan seperti ikan dan tata kehidupan lainnya. Untuk itu pemantauan kondisi oksigen terlarut sangat penting artinya bagi tatanan kehidupan perairan tersebut. Konsentrasi oksigen terlarut di dalam perairan dipengaruhi oleh suhu, ada tidaknya tumbuhan yang berfotosintesa, dapat tidaknya perairan tersebut ditembus oleh sinar matahari, adanya goncangan dalam air dan banyaknya senyawa organik yang harus diuraikan di dalam air. Oksigen terlarut dalam air sungai, kolam dan danau berasal dari udara dan sebagian lagi berasal dari hasil fotosintesis tumbuhan yang ada di dalam air. Pada bagian perairan yang sangat dalam, tumbuhan tidak memperoleh energi matahari, sehingga fotosintesis tidak bekerja dan konsentrai oksigen sangat kecil.

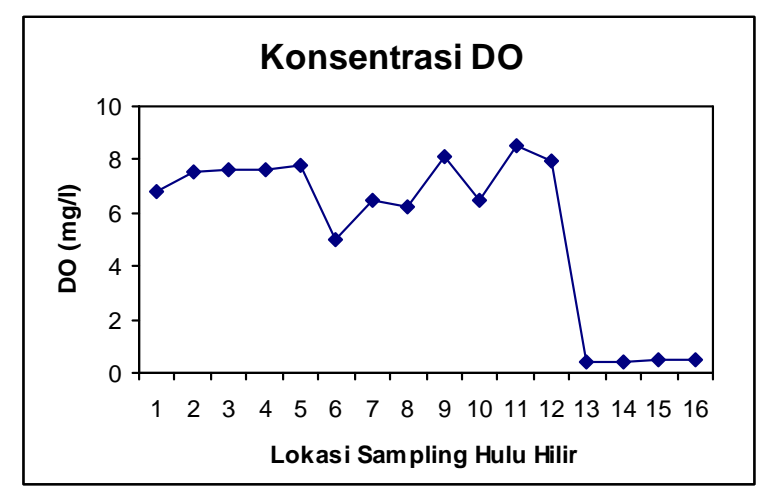

Gambar 7. Konsentrasi DO di Sungai Ciliwung Hulu-Hilir

Berdasarkan parameter oksigen terlarut hasil pengukuran pada kegaitan ini, Sungai Ciliwung pada segmen hulu dan tengah menunjukan kisaran angka 4,96 - 8,12 mg/L, berada diatas baku mutu kualitas air yaitu 0-6 $\mathrm{mg} / \mathrm{L}$. Sedangkan untuk segmen hilir menunjukkan angka DO yang jauh lebih rendah yaitu $<1 \mathrm{mg} / \mathrm{L}$, hal ini terjadi terkait dengan tingginya pencemaran limbah domestik di daerah hilir, selain itu juga morfologi sungai yang datar/landai menyebabkan aliran air sangat lambat dan tidak terjadi pergolakan di permukaan air (turbulensi). Kondisi oksigen terlarut di Sungai Ciliwung dari hulu hingga hilir disajikan pada Gambar 7.

\section{e. Total Padatan Tersuspensi (Total Suspended Solid)}

Total padatan terdiri dari padatan terlarut dan padatan tersuspensi dalam air atau air limbah, total padatan dapat mempengaruhi kualitas air antara lain rasa dan dapat menginduksi reaksi fisiologi yang kurang baik pada level konsumen. Konsentrasi padatan terlarut maksimum untuk air minum adalah 500 ppm. Air dengan kadar mineral tinggi tidak cocok digunakan di industri. Padatan tersuspensi di perairan dapat berupa fitoplankton, zooplankton, mikroba yang hidup atau mati, kotoran manusia dan binatang, bagian dari tanaman, atau binatang yang sedang terdekomposisi dan limbah industri. Air dengan kadar padatan tersuspensi tinggi tidak sesui untuk keperluan mandi. Analisis ini penting dilakukan untuk monitoring terkait dengan pembuangan limbah yang masuk ke Sungai Ciliwung.

Hasil analisis menunjukan bahwa kandungan padatan tersuspensi di perairan Sungai Ciliwung berkisar antara 3-8,5 mg/L, terendah terjadi di daerah hulu sungai ciliwung 
karena masukan limbah masih tergolong sedikit, sebaliknya tertinggi di daerah hilir karena akumulasi masukan limbah berbagai aktivitas masyarakat. Secara umum pola yang terjadi adalah semakin ke hilir padatan tersuspensi semakin tinggi, hal ini mencerminkan bahwa masukan limbah meningkat dari hulu ke hilir. Sebaran total padatan tersuspensi di Sungai Clliwung mulai hulu hingga hilir disajikan pada Gambar 8.

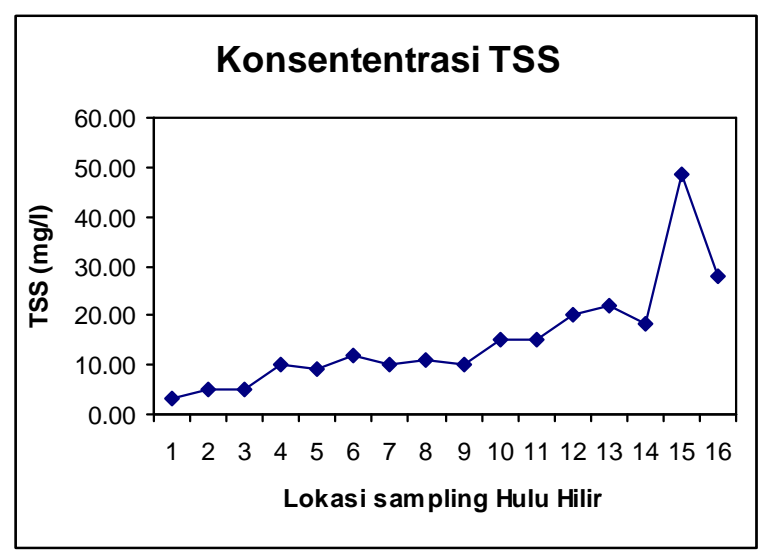

Gambar 8. Konsentrasi TSS di Sungai Ciliwung Hulu-Hilir

\section{f. Konsentrasi Fecal Coli}

Bakteri Escherichia coli merupakan bakteri fecal coli yang umum digunakan sebagai parameter sanitasi karena bakteri E. coli merupakan indikator adanya pencemaran fekal dan bakteri patogen dalam makanan dan air, serta deteksinya lebih mudah dan murah dibandingkan dibandingkan dengan deteksi bakteri patogen. Bahkan, beberapa strain bakteri E. Coli tertentu telah diketahui dapat bersifat patogen dengan timbulnya gejala-gejala menyerupai gejala penyakit Cholera dan Shigellosis.

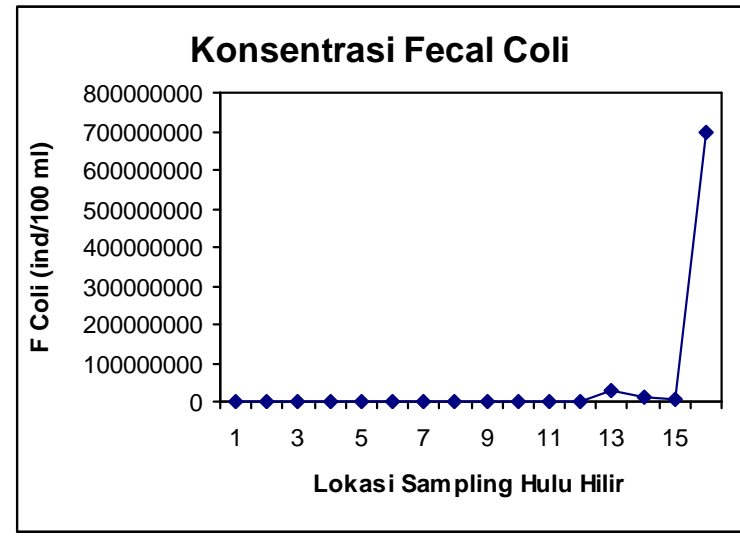

Gambar 9. Konsentrasi Fecal Coli di Sungai Ciliwung Hulu-Hilir
Sumber utama bakteri ini adalah limbah domestik berupa kotoran/tinja. Hasil analisis menunjukkan bahwa kandungan $E$. Coli di perairan Sungai Ciliwung memiliki nilai yang tinggi jauh di atas BMA yang telah ditetapkan untuk standar kesehatan masyarakat. Hasil analisis kandungan fecal coli mencapai 49.000$24.000 \mathrm{jml} / 100 \mathrm{ml}$ (hulu dan tengah) dan 4.900.000-1.700.000.000 jml/100 ml. Hal ini menunjukan bahwa air dari Sungai Ciliwung tidak layak untuk bahan baku air minum. Tingginya angka ini disebabkan tingginya volume limbah domestik yang masuk ke perairan Sungai Ciliwung. Sebaran fecal coli di Sungai Ciliwung disajikan pada Gambar 9.

\section{g. Konsentrasi Coliform}

Bakteri coliform umumnya digunakan sebagai indikator bakteri untuk kualitas makanan dan air. Coliform banyak ditemukan di dalam tinja dari hewan-hewan berdarah panas, tetapi dapat juga ditemukan di lingkungan perairan, tanah dan vegetasi. Secara umum coliform itu sendiri tidak mengakibatkan sakit, tetapi mereka mudah berkembangbiak dan keberadaannya digunakan untuk menunjukan bahwa organisme patogen lain juga ada.

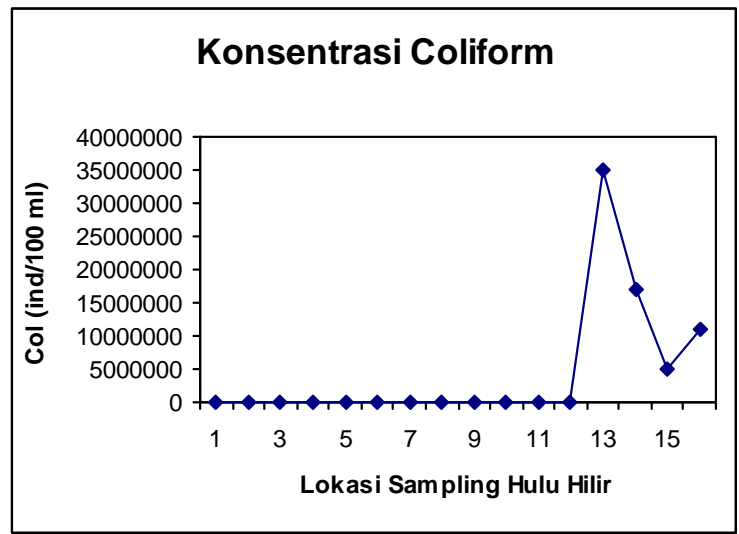

Gambar 10. Konsentrasi Coliform di Sungai Ciliwung Hulu-Hilir

Hasil pengukuran menunjukan bahwa konsentrasi coliform di perairan Sungai Ciliwung memiliki nilai yang tinggi berkisar antara 49.000$240.000 \mathrm{jml} / 100 \mathrm{ml}$ (segmen hulu-tengah) dan 4.900.000-17.000.000 jml/100 ml, jauh di atas BMA yaitu 1000-1000 jml/ $100 \mathrm{ml}$. Pola distribusinya meningkat pada saat di segmen hilir, hal ini terkait dengan tingginya limbah domestik tinja di hilir yang masuk perairan Sungai Ciliwung. Sebaran distribusi konsentrasi coliform mulai hulu-hilir disajikan pada Gambar 10. 


\section{h. Konsentrasi Phosphat}

Phosphate $\left(\mathrm{PO}_{4}\right)$ memiliki unsur utama phosphorus yang merupakan unsur penting untuk nutrisi tanaman dan hewan. Kebanyakan phosphorus dikonsumsi dalam bentuk komponen pupuk Nitrogen, Phosphor, dan Kalium/Potassium yang digunakan untuk pemupukan tanaman baik tanaman pangan maupun tanaman lainnya. Penggunaan pupuk ini sudah menjadi suatu keharusan dalan setiap kegiatan bercocok tanam, dampaknya penggunaan yang berlebihan menjadi masalah terhadap lingkungan termasuk perairan sungai. DAS Sungai Ciliwung di daerah hulu terdapat penggunaaan lahan untuk kegiatan pertanian tanaman pangan, sayuran dan lain-lain, oleh karena itu pemantauan tehadap phosphor ini penting dilakukan untuk mengetahui konsentrasi yang ada di dalam lingkungan perairan ini. Dampak yang akan terjadi di sungai apabila terjadi kelebihan konsentrasi phosphor adalah terjadinya eutrofikasi atau penyuburan perairan yang mengakibatkan ketidakseimbangan ekosistem perairan, sehingga biota yang ada menjadi terganggu.

Hasil analisis menunjukan bahwa konsentrasi phosphor di perairan Sungai Ciliwung dari hulu ke hilir memiliki nilai dengan kisaran antara 0,04-2,15 mg/L, berada di sekitar BMA yaitu antara 0,2 sampai $5 \mathrm{mg} / \mathrm{L}$. Berdasarkan hal tersebut maka dari parameter ini perairan Sungai Ciliwung masih pada tingkat aman. Sebaran konsentrasi Phosphat di Sungai Ciliwung hulu ke hilir disajikan pada Gambar 11.

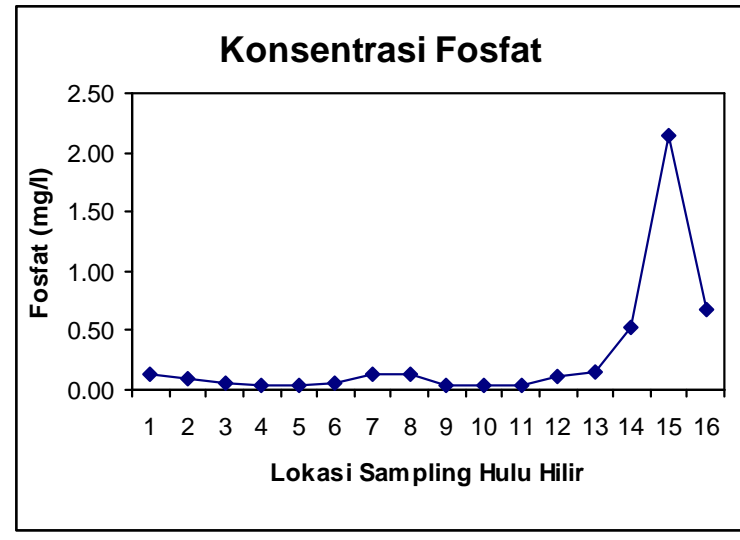

Gambar 11. Konsentrasi Phosphat di Sungai Ciliwung Hulu-Hilir

\section{i. Konsentrasi Nitrogen}

Nitrogen dalam lingkungan perairan terdapat sebagai gas N2 yang larut, senyawa organik seperti ammonia, nitrit, nitrat, dan senyawa organik berupa protein dan urea. Gas berasal dari udara dan laut dalam perairan tidak menunjukan adanya pencemaran. Ammonia dalam air merupakan hasil penguraian senyawa organik dan dalam air biasanya berbentuk $\mathrm{NH}^{4+}$. Keberadaan ammonia dalam air kemungkinan disebabkan adanya kotoran binatang atau manusia atau juga berasal dari pupuk. Ammonia dapat mengganggu penjernihan air karena dapat mengurangi aktivitas $\mathrm{Cl}_{2}$ dalam membunuh kuman.

Nitrit dalam air sebagai hasil oksidasi ammonia oleh bakteri dan biasanya kadarnya kecil. Kadar nitrit yang besar mungkin berasal dari limbah industri. Penilaian terhadap nitrit menunjukan jumlah zat nitrogen yang hanya sebagian saja mengalami oksidasi. Dengan demikian nitrit merupakan suatu tingkat peralihan dalam proses perubahan zat organik ke dalam bentuk yang tetap. Nitrit, oleh karena itu tidak dapat ditemukan dalam air limbah baru kecuali dalam jumlah kecil sekali. Namun demikian nitrit tidak dapat tetap dan dapat menurun menjadi ammonia atau dioksidasikan menjadi nitrat, keberadaan nitrit dan nitrat menunjukan bahwa perubahan sedang berlangsung. Dengan demikian terdapatnya nitrit menunjukkan adanya limbah yang kondisinya mencemari atau tidak dapat diuraikan secara sempurna.

Nitrat mewakili produk akhir dari pengoksidasian zat yang bersifat nitrogen. Jadi jumlah nitrat itu menunjukkan lajunya pembenahan menuju oksidasi lengkap dan kemantapan. Penentuan nitrat sangat terkait erat dengan proses terjadinya penguraian limbah dalam perairan. Hasil analisis nitrogen total di perairan Sungai Ciliwung menunjukan nilai berkisar antara 1,09 sampai 9,19 mg/L. Angka tersebut masih dibawah BMA yaitu antara 10-20 $\mathrm{mg} / \mathrm{L}$. Namun demikian apabila dilihat dari polanya kandungan $\mathrm{N}$ total ini semakin ke hilir terus meningkat, hal ini terkait dengan semakin meningkatnya bahan-bahan organik limbah pada segmen hilir. Sebaran konsentrasi nitgrogen total di Sungai Ciliwung hulu hingga hilir disajikan pada Gambar 12.

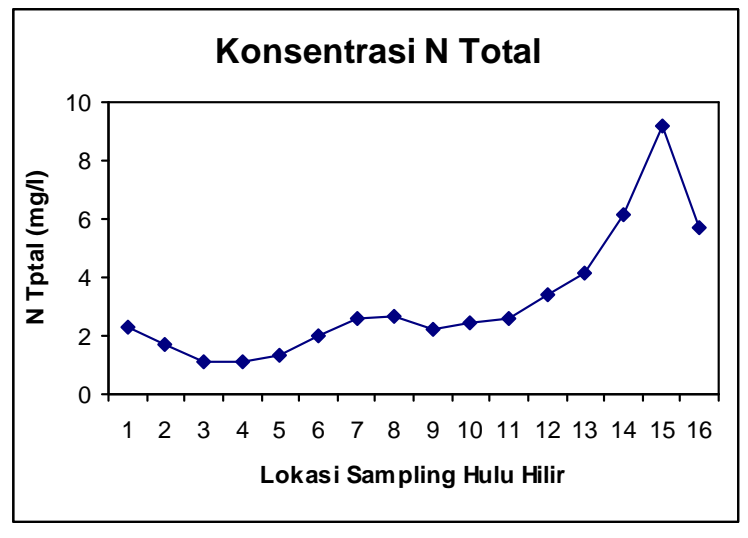

Gambar 12. Konsentrasi N-Total di Sungai Ciliwung Hulu-Hilir 


\section{KESIMPULAN}

a. $\mathrm{pH}$ semakin kehilir konsentrasi semakin besar, tetapi masih dalam selang baku mutu lingkungan.

b. Konsentrasi BOD perairan sungai Ciliwung dari hulu hingga hilir sudah melampaui ambang batas baku mutu lingkungan sesuai dengan target BMA tiap segmen.

c. Dari target baku mutu yang diinginkan, konsentrasi COD di segmen hulu sebagian berada di atas BMA, sedangkan segmen tengah dan hilir masih berada dibawah ambang baku mutu air yang ditargetkan.

d. Konsentrasi oksigen terlarut pada segmen hulu dan tengah berada diatas baku mutu air yang ditetapkan tiap segmen, sedangkan pada bagian segmen hilir konsentrasinya berada jauh dari target baku mutu air yang diinginkan.

e. Konsentrasi padatan tersuspensi (Total Suspended Solid) semakin ke hilir semakin tinggi.

f. Konsentrasi Fecal Coli dan Coliform dari hulu hingga hilir juga menunjukkan konsentrasi yang semakin tinggi dan jauh berada di atas baku mutu air yang ditetapkan.

g. Konsentrasi Nitrogen dari hulu ke hilir semakin tinggi, akan tetapi kualitasnya masih dibawah baku mutu air yang ditetapkan.

\section{DAFTAR PUSTAKA}

1. Nomor 82 Tahun Kualitas Ar dan Pengendalian Pencemaran Air.

2. 2002. Depok Dalam Angka Tahun 2002. BPS.

3. 2005. Kabupaten Bogor Dalam Angka Tahun 2005. BPS.

4. APHA. 1989. Standard Methods for the Examination of Water and Wastewater, $15^{\text {th }}$ ed. New York.

5. BPPT. 2007. Penyusunan Pola Pengelolaan DAS Siak, Provinsi Riau. Balitbangda Provinsi Riau. Jakarta.

6. Departemen Kehutanan, (2001). Pedoman Penyelenggaraan Pengelolaan Daerah Aliran Sungai. Kep.Men.Hut. No.52/Kpts-II/2001. Tentang. Pedoman Penyelenggaraan Pengelolaan DAS. DitJen RLPS. Dit. RLKT.

7. Effendi, H. (2003). Telaah Kualitas Air Bagi Pengelolaan Sumber Daya dan Lingkungan Pengairan. Penerbit Kanisius. Yogyakarta.

8. Fullazzaki, M.A., (2005), Assessment of Water Quality Degradation for the Citarum and Brantas River Using A New Developed Water Quality Index System, in Proceeding of International Symposium on Ecohydrology, IHP-UNESCO, Kuta-Bali.

9. Sastro Hardjono, S. 2007. Kelembagaan Pengelola Sumberdaya Air Wilayah Sungai Ciliwung Cisadane. Jakarta. 
Tabel Lampiran 1. Data Kualitas Air Sungai Ciliwung dari Hulu hingga Hilir hasil Pemantauan September 2007.

\begin{tabular}{|r|l|r|r|r|r|r|r|r|r|r|}
\hline No & Parameter & \multicolumn{1}{|c|}{$\mathbf{2}$} & $\mathbf{3}$ & $\mathbf{4}$ & $\mathbf{5}$ & $\mathbf{6}$ & $\mathbf{7}$ & $\mathbf{8}$ & $\mathbf{9}$ \\
\hline 1 & pH & 6,6 & 6,9 & 7,4 & 7,2 & 7,4 & 7,3 & 7,7 & 7,7 & 7,4 \\
\hline 2 & BOD & 14,50 & 12,45 & 5,65 & 7,55 & 9,10 & 7,95 & 10,85 & 9,65 & 11,06 \\
\hline 3 & COD & 28,57 & 25,71 & 7,62 & 13,81 & 17,62 & 15,24 & 20,95 & 13,33 & 26,71 \\
\hline 4 & DO & 6,8 & 7,57 & 7,64 & 7,66 & 7,81 & 4,96 & 6,5 & 6,19 & 8,12 \\
\hline 5 & TSS & 3 & 5 & 5 & 10 & 9 & 12 & 10 & 11 & 10 \\
\hline 6 & Fecal Coli & 49.000 & 920.000 & 33.000 & 33.000 & 240.000 & 130.000 & 240.000 & 79.000 & 130.000 \\
\hline 7 & Coliform & 49.000 & 170.000 & 240.000 & 70.000 & 240.000 & 130.000 & 240.000 & 240.000 & 130.000 \\
\hline 8 & Fosfat & 0,13 & 0,1 & 0,06 & 0,04 & 0,04 & 0,06 & 0,13 & 0,14 & 0,03 \\
\hline 9 & N-Total & 2,31 & 1,67 & 1,09 & 1,09 & 1,33 & 1,99 & 2,58 & 2,65 & 2,21 \\
\hline
\end{tabular}

\begin{tabular}{|r|l|r|r|r|r|r|r|r|}
\hline No & Parameter & \multicolumn{1}{|c|}{10} & \multicolumn{1}{c|}{11} & \multicolumn{1}{c|}{12} & 14 & 15 & 16 \\
\hline 1 & $\mathrm{pH}$ & 7,4 & 6,9 & 7,2 & 7,1 & 7,4 & 7,4 & 7,6 \\
\hline 2 & BOD & 11,55 & 20,50 & 29,90 & 21,80 & 26,20 & 50,60 & 60,00 \\
\hline 3 & COD & 28,51 & 27,62 & 44,48 & 30,48 & 41,9 & 98,24 & 68,57 \\
\hline 4 & DO & 6,44 & 8,5 & 7,98 & 0,4 & 0,37 & 0,48 & 0,5 \\
\hline 5 & TSS & 15 & 15 & 20 & 22 & 18,5 & 48,5 & 28 \\
\hline 6 & Fecal Coli & 110.000 & 130.000 & 49.000 & 28.000 .000 & 110.000 .000 & 4.900 .000 & 1.700 .000 .000 \\
\hline 7 & Coliform & 49.000 & 130.000 & 79.000 & 35.000 .000 & 17.000 .000 & 4.900 .000 & 11.000 .000 \\
\hline 8 & Fosfat & 0,04 & 0,04 & 0,11 & 0,15 & 0,53 & 2,15 & 0,68 \\
\hline 9 & N-Total & 2,47 & 2,58 & 3,39 & 4,14 & 6,12 & 9,19 & 5,7 \\
\hline
\end{tabular}

Sumber : Hasil Survei Lapang dan Analisis Laboratorium dari BPLH Prop DKI Jakarta, 2007

\section{Keterangan:}

\section{Masjid Atta'awun \\ 2 Cisampai \\ 3 Leuwi Malang \\ 4 Jembatan Gadog}

$\begin{array}{llrl}5 & \text { Pasir Angin } & 9 & \text { Pondok Rajek } \\ 6 & \text { Katulampa } & 10 & \text { Jembatan Panus } \\ 7 & \text { Kebun Raya } & 11 & \text { Jembatan Kelapa Dua } \\ 8 & \text { Pasir Jambu } & 12 & \text { Condet }\end{array}$

13 Manggarai

14 Kwitang

15 Gn Sahari

16 Pantai Indah Kapuk 